\title{
Recent Experiences in the Rapid Identification of Bacterium coli Type I
}

\author{
By E. F. W. MACKENZIE, E. W. TAYLOR AND W. E. GILBERT \\ From the Laboratories of the Metropolitan Water Board, London
}

SUMMARY: When using MacConkey broth medium incubated at $44^{\circ}$ as a confirmatory test for Bacterium coli Type I, positive reactions were produced by anaerobic lactose-fermenting bacteria such as Clostridium welchii. The use of brilliant green bile broth instead of MacConkey broth was completely successful in suppressing the growth of these organisms at $44^{\circ}$, but did not influence the growth of Bact. coli Type I. Two other coliform organisms, namely, Irregular Type II and Irregular Type VI were found to ferment lactose at $44^{\circ}$. A rapid test for their differentiation from Bact. coli Type I has been based upon the ability of that organism to produce indole at $44^{\circ}$, whereas the two irregular types are indole negative. By subculture of presumptive positive tubes in brilliant green bile broth and peptone water together with incubation at $44^{\circ}$, an estimation of the Bact. coli content of a water sample may be obtained within $48 \mathrm{hr}$. of primary inoculation.

It is now over 40 years since Eijkman showed that coliform bacteria from the intestines of warm-blooded animals would grow and produce gas in glucose broth at a temperature of $46^{\circ}$, whereas coliforms from the intestines of coldblooded animals would not. Modifications of the Eijkman test with regard to medium and temperature have been introduced from time to time and Wilson, Twigg, Wright, Hendry, Cowell \& Maier (1935) considerably modified the test and recommended its use for the routine detection of Bacterium coli (Escherichia coli) in samples of milk. The test, as then modified, consisted of fermentation of MacConkey broth at $44^{\circ}$ in an accurate, thermostatically controlled waterbath. It has the advantage over the older plating method of considerable saving in time, labour and cost. The method was advocated for the detection of Bact. coli Type I in water analysis by Mackenzie \& Hilton-Sergeant (1938), and a further series of comparative tests were reported by Mackenzie (1938). The test was officially recommended for routine work in the Ministry of Health Report, No. 71 (1939). A full bibliography was published by Batty-Smith (1942) so that further reference to the literature is unnecessary.

Two procedures were suggested by Wilson et al., either the direct inoculation of the milk sample into tubes of media and incubation at $44^{\circ}$, or the subculture of primary positive tubes from the first $24 \mathrm{hr}$. at $37^{\circ}$ into MacConkey medium and incubation of these at $44^{\circ}$. It was found (Mackenzie, 1938) that for riverwater samples, where Bact. coli was abundant, primary incubation at $44^{\circ}$ was as efficient as the subculture procedure; but when stored, filtered and chlorinated water samples were tested, the organisms, possibly because of attenuation, were more frequently recovered by the subculture procedure than by direct inoculation at $44^{\circ}$. Since, in addition, very large incubator baths would have been needed to accommodate the groups of tubes to be set up for each test, the subculture procedure for the rapid identification of Bact. coli was chosen for our laboratories and first used as a routine test in September 1939. It is now 


\section{E. F. W. Mackenzie, E. W. Taylor and W. E. Gilbert}

being employed successfully at many other laboratories in Great Britain and elsewhere.

This paper contains an account of experiences with the $44^{\circ}$ test, and of certain modifications that have been introduced from time to time which have considerably enhanced the value of the test as a means for the rapid identification of Bact. coli Type I.

\section{Water-bath at $44^{\circ}$}

An essential feature of the test is that the medium should be maintained at the prescribed temperature with only very slight deviation. If this cannot be done it is inadvisable to use the test. In our laboratories an almost constant temperature has been achieved and a detailed description of the method used may therefore be of value.

A copper bath, provided with a closely fitting lid, is set up in a thermostatically controlled cupboard, the temperature of which is then regulated empirically to maintain the water in the bath at $44^{\circ}$. The temperature is recorded by a thermometer immersed in the bath which gives a continuous record on a chart situated outside the incubator rooms. The record indicates whether any electrical breakdown has occurred during the period of incubation. In addition, an accurate thermometer calibrated to $1 / 50$ th of a degree Centigrade is kept in the bath and is observed once daily as a control. The cupboard and bath are opened only twice daily, with precautions to prevent cold air entering the apparatus, the cupboard being approached through a heated and thermostatically controlled entrance chamber. After inoculation, the tubes are rapidly heated to $44^{\circ}$ in a separate water-bath before being placed in the special incubator. Fifty $\mathrm{ml}$. water, previously heated to $44^{\circ}$, are added to the bath periodically to replace that lost by evaporation. When all these precautions are observed the temperature deviation never exceeds $0 \cdot 1^{\circ}$.

\section{Incubation in brilliant green bile broth at $44^{\circ}$.}

In all the work recently described single strength MacConkey broth medium has been employed for the test. When using this medium we noticed that subcultures from some presumptive positive tubes gave vigorous gas production at $44^{\circ}$ but only slight acidity, the litmus indicator changing to purple

rather than to red or orange, and that when these presumptive positive tubes were plated on MacConkey agar no growth occurred. This reaction-'purple' acidity with good gas production-occurred most frequently in chlorinated waters and proved to be caused by anaerobic lactose fermenting organisms. Clostridium welchii ( $\mathrm{Cl}$. perfringens) and other bacteria of this group could be isolated from 5 to $\mathbf{1 0} \%$ of all positive tubes from samples of London waters, and it was the cultures from these tubes which gave the 'purple' reaction.

In an endeavour to overcome this disadvantage, tests were made of several different media and two, brilliant green bile broth and standard MacConkey broth, were selected for detailed comparison. The brilliant green bile broth was made up as follows (American Public Health Association, 1936): Bacto ox 
gall, 30 g.; Bacto peptone, 15 g.; lactose, 15 g.; Bacto brilliant green (1 \% w/v), $2 \mathrm{ml}$; and distilled water to $1500 \mathrm{ml}$., the $\mathrm{pH}$ being adjusted to $7 \cdot 2-7 \cdot 4$.

Each day, a number of presumptive positive tubes were selected from the routine work, particular care being taken to include tubes likely to produce the 'purple' reaction in MacConkey broth at $44^{\circ}$, and subcultures made into singlestrength MacConkey broth and into single-strength brilliant green bile broth. Both series of tubes were incubated in the $44^{\circ}$ water-bath for $24 \mathrm{hr}$. Positive results in MacConkey broth were indicated by the production of acid and gas; positive results in brilliant green bile broth were indicated by gas production but there was, of course, no change in colour as occurs in MacConkey broth. Occasionally gas production was slight in brilliant green bile broth, and could be demonstrated only by sharply tapping the tube with a ruler or pencil. Cultures exhibiting any degree of gas production in this medium, however slight, almost invariably proved to contain Bact. coli Type I. In all, 1419 tubes positive in the presumptive coliform test were tested in this way. Table 1 shows the number of positive reactions obtained with each medium, and the number which was subsequently proved to have been due to Bact. coli Type I (acid and gas in lactose, indole positive, no growth in citrate, methyl red test positive, Voges-Proskauer test negative and $44^{\circ}$ test positive).

Table 1. Comparison of results of subculture of 1419 primary positive cultures into brilliant green bile broth and MacConkey broth at $44^{\circ}$

\begin{tabular}{|c|c|c|}
\hline & $\begin{array}{c}\text { No. of subcultures } \\
\text { reacting } \\
\text { positively } \\
\text { at } 44^{\circ}\end{array}$ & $\begin{array}{c}\text { No. of positive subcultures } \\
\text { yielding Bact. coli } \\
\text { Type I }\end{array}$ \\
\hline MacConkey broth & 431 & $314(72.8 \%)$ \\
\hline Brilliant green bile broth & 319 & $313(98 \cdot 1 \%)$ \\
\hline
\end{tabular}

Brilliant green bile broth was markedly superior to MacConkey broth for confirmation of Bact. coli Type I at $44^{\circ}$ and was adopted as the routine medium on 1 June 1941. Thousands of positive tubes have since been plated and the organisms responsible for the positive reactions identified. In no case has a positive reaction been found to be due to an anaerobic lactose-fermenting bacterium.

\section{Irregular coliform types growing at $44^{\circ}$}

Beside Bact. coli Type I, two other coliform types can grow at $44^{\circ}$, namely Irregular Type II and Irregular Type VI. Their primary habitat has not, however, been established as faecal.

Irregular Type II. Its reactions are acid and gas in lactose, indole negative, no growth in citrate, methyl red test positive, Voges-Proskauer test negative, $44^{\circ}$ test positive.

It is an indole negative variety of Bact. coli Type I and is classified by Wilson et al. (1935) as Irregular Type II. Its frequency in human faeces is low. For example, from a series of $\mathbf{7 8 0}$ specimens from apparently healthy individuals, examined by the authors during routine examinations for typhoid carriers, Irregular Type II was found in only $20(2 \cdot 6 \%)$. Comparative figures for 
Intermediates (Escherichia freundii) and Bacterium aerogenes (Aerobacter aerogenes) were $30(3.8 \%)$ and $8(1.0 \%)$ respectively.

Unfortunately, the majority of the strains from human excrement were isolated during the war when circumstances precluded a detailed study of all of them. A special study of sixty-four strains of Irregular Type II has, however, been made, fifty-nine isolated from water and five from faeces. The cultures were maintained for 6 years by plating alternately on nutrient gelatine and agar media at intervals of 2-3 months. From time to time the reactions of the strains were re-examined, with the following results (Table 2): (1) all reactions remained constant for the whole 6 years, except indole production; (2) a high proportion of the strains isolated from water became indole positive; (3) none of the faecal strains became indole positive.

Table 2. Acquisition of power to produce indole by Bacterium coli Irregular Type II

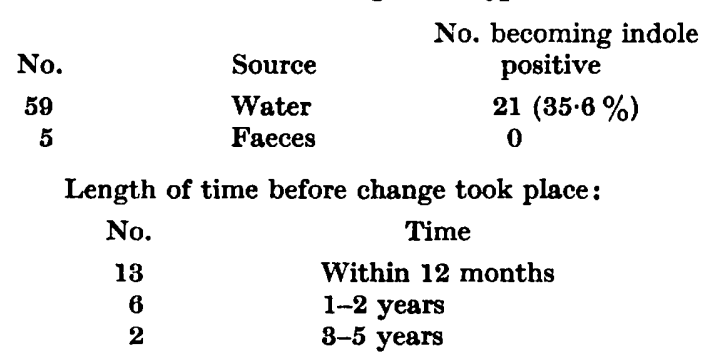

Each of these mutating strains was carefully investigated, and in all cases it was found that an indole negative strain produced a mixture of indole positive and indole negative colonies on subculture, the former breeding true indole positives on further subculture, whilst the latter again gave off a mixture of indole positive and negative varieties. Table 3 illustrates a typical experience; the strain was plated out and thirty colonies were subcultured, each into a large tube of peptone water which was tested for indole at intervals. It will be seen that one single-colony strain remained obstinately indole negative, but after several subcultures over a year, a peptone water subculture from the stock agar slope gave a positive indole reaction, indicating that mutation was still taking place.

Table 3. Indole production at $37^{\circ}$ in peptone water subcultures of thirty single colonies of a strain of Bacterium coli Irregular Type $I I$

$\begin{array}{lcccccccc}\text { Days } & 2 & 4 & 6 & 8 & 10 & 14 & 21 & 28 \\ \text { positive reactions } & 1 / 30 & 2 / 30 & 10 / 30 & 17 / 30 & 19 / 30 & 21 / 30 & 27 / 30 & 29 / 30\end{array}$

$\begin{array}{lllllllll}\text { Number of positive reactions } & 1 / 30 & 2 / 30 & 10 / 30 & 17 / 30 & 18 / 30 & 21 / 30 & 27 / 30 & 29 / 30\end{array}$ in thirty subcultures

When this coliform type mutates to an indole positive variety it is indistinguishable from Bact. coli Type I, and there seem, therefore, good grounds for considering it as a faecal type. On the other hand, no mutation was observed in any of the five strains actually isolated from faeces. The number examined is admittedly small, and more work is required on these intestinal 
strains. Another view is that the mutating specimens isolated from water are attenuated Bact. coli Type I strains which revert to their true reactions under better environmental conditions. If such is the case, then again Irregular Type II should be considered as a true faecal type. A somewhat paradoxical situation thus arises. Irregular Type II, when isolated from water, may mutate when subcultured for a sufficiently long period, and become indistinguishable from Bact. coli Type I. An organism producing the same original reactions to all commonly used tests, when isolated from the animal intestine, has retained the characteristic which distinguishes it from Bact. coli Type I. From this it might be argued that Irregular Type II isolated from water is a typical faecal Bact. coli which, by attenuation, has lost its power to produce indole, whereas the same organism, when isolated from human excrement, does not fit into the classification of faecal coliforms. Any division of the coliform bacteria into faecal and non-faecal types must, however, depend not only upon biological reactions, but upon the frequency with which each type can be isolated from the intestines of warm-blooded animals, making due allowance for the undoubted fact that typically non-faecal coliforms may be found in excrement through accidental ingestion with foods, and typically faecal coliforms are frequently found outside the intestine as a result of contamination with excrement.

Table 4 shows coliform types from filtered and chlorinated water and how seldom Irregular Type II is isolated. Its classification is, therefore, of academic interest rather than of practical importance in water analysis.

Table 4. (a) Frequency of isolation of coliform types from filtered and chlorinated water

Number of samples

Number containing coliforms

15,770

Number containing Bact. coli Type I

(b) Classification of the coliform types isolated

Coliform types isolated
Bact. coli Type I
Irregular Type I
Irregular Type II
Bact. coli Type II
Intermediates
Bact. aerogenes
Irregular Type VI

425 $225(52.9 \%)$

$10(2.4 \%)$

$4(0.9 \%)$

$5(1 \cdot 2 \%)$

$86(20 \cdot 2 \%)$

$62(14.6 \%)$

$83(7 \cdot 8 \%)$

Irregular Type VI. The other coliform organism which gives a strong reaction at $44^{\circ}$ has otherwise all the attributes of Bact. aerogenes, namely, acid and gas in lactose, indole negative, growth in citrate, methyl red negative, Voges-Proskauer positive.

This organism is rarely found in faeces in England, occurring only twice in the series of 780 examinations mentioned above. It is most frequently isolated from water samples collected from new or repaired water mains and wells (Whiskin \& Taylor, 1945). The source in these cases has been traced to jute yarn used as a jointing material in mains and as a packing in well pumps. For this reason it has been named the 'yarn' organism, but is Irregular 
Type VI in Wilson's classification of coliforms. It has also been isolated from decaying wood; for example, a coliform count of $16 / \mathrm{ml}$. was obtained from a sample of well water which had been negative for coliform bacteria for some months previously. All primary tubes gave a positive confirmatory $44^{\circ}$ test and Irregular Type VI was isolated in pure culture. Investigation ultimately traced the origin of the infection to decaying wood in the adits of the well, from which material the type was freely cultured.

Irregular Type VI is much more common in India, being isolated frequently from stools and for that reason the $44^{\circ}$ test has not gained favour there (Raghavachari \& Iyer, 1939; Boizot, 1941). Information kindly supplied by dealers in yarn packing is to the effect that much of the jute fibre is imported from Calcutta and is then spun and made up in this country. Irregular Type VI is constantly found in this material and it seems highly probable that these organisms are imported in the jute, and that there is sufficient moisture on the fibre to keep the organisms alive. They survive the manufacture into yarn and, under the favourable temperature conditions ruling during the summer months in this country, the organisms multiply in the yarn and on appearing in water samples are responsible for failures of the $44^{\circ}$ test as an indicator of Bact. coli Type I similar to those reported from India.

This coliform organism is capable of surviving for long periods and multiplying in jute, and the use in waterworks of jute yarn or other materials infected with it is to be deprecated, otherwise water supplies are likely to be condemned owing to its presence. When Irregular Type VI is suspected as being the cause of a positive reaction to the $44^{\circ}$ test it is necessary to plate out and type the organism fully before an opinion can be given on the safety of the water. This procedure requires 5 days and causes much unnecessary delay.

\section{The differential value of indole production at $44^{\circ}$}

Production of indole is characteristic of Bact. coli Type I and is shared only by four other coliform organisms, namely, Irregular Types I and VII, Intermediate Type II and Bact. aerogenes Type II. On the other hand, these organisms differ from Bact. coli Type I in that they are incapable of fermenting lactose at $44^{\circ}$. Again, of the three coliform organisms that are able to ferment lactose at $44^{\circ}$, only one, namely Bact. coli Type I, produces indole. It therefore appeared that, if $B$ act. coli Type I were capable of indole production at $44^{\circ}$ in pure and in mixed culture, then a rapid mode of differentiation was available.

Accordingly several cultures were tested for indole production in the waterbath at $44^{\circ}$ (Table 5).

All Bact. coli Type I strains produced indole at $44^{\circ}$, and all intermediate and aerogenes strains failed to do so. Six of the seventeen Irregular Type I strains produced indole at $44^{\circ}$, and it is known that four of these were isolated from stools. Thus, by inoculating from a primary positive tube into brilliant green bile broth and a tube of peptone water for indole production and incubating both at $44^{\circ}$ for $24 \mathrm{hr}$., the resulting reactions would indicate Bact. coli Type I, or other coliform bacteria as shown in Table 6 . 
An anomalous result would occur if there were a mixture of Irregular Type VI and certain strains of Irregular Type I. Such a combination, however, would be extremely rare.

In an endeavour to ascertain whether small numbers of Bact. coli can be detected by indole formation at $44^{\circ}$, even when growing in competition with Irregular Type VI, a few experiments were devised of which the following is

Table 5. Indole production at $44^{\circ}$ by various coliform types

$\begin{array}{lcccc}\quad \text { No. of strains } & \overbrace{37^{\circ}} \begin{array}{c}\text { Strains producing } \\ \text { indole at }\end{array} & \begin{array}{c}\text { Strains producing gas } \\ \text { in brilliant green bile } \\ \text { broth at } 44^{\circ}\end{array} \\ \text { Bact. colif Type I } & \mathbf{5 9} & \mathbf{5 9} & \mathbf{5 9} & \mathbf{5 9} \\ \text { Irregular Type I } & 17 & 17 & 6 & 0 \\ \text { Intermediate Type II } & 12 & 12 & 0 & 0 \\ \text { Bact. aerogenes Type II } & 19 & 19 & 0 & 0\end{array}$

Table 6. Differentiation of coliform types by gas production in brilliant green bile broth at $44^{\circ}$ and indole production at $44^{\circ}$

$\begin{array}{ccc}\begin{array}{c}\text { Gas in brilliant green } \\ \text { bile broth at } 44^{\circ}\end{array} & \begin{array}{c}\text { Indole production } \\ \text { at } 44^{\circ}\end{array} & \\ + & + & \text { Bact. coli Type I } \\ + & 0 & \text { Irregular Type II } \\ \text { Irregular Type VI } & \text { Other coliforms } \\ 0 & + & \text { Other coliforms }\end{array}$

an example. A series of seven tubes of brilliant green bile broth and seven of peptone water were each inoculated with about sixteen viable Bact. coli Type I and with a volume of suspension of Irregular Type VI sufficient to give a concentration in the different tubes varying from 150 to 150,000 organisms. The numbers of organisms in the inocula were estimated by MacConkey plate counts. Following $24 \mathrm{hr}$. incubation at $44^{\circ}$ all the peptone water tubes were positive by the indole test and all brilliant green bile broth tubes showed gas production. It was to be expected that the brilliant green bile broth tubes would develop gas with either organism but the presence of Bact. coli Type I was demonstrated by the indole test even in as low an initial ratio as about $1: 10,000$.

This experiment indicates the sensitivity of the $44^{\circ}$ indole test for Bact. coli Type $I$ even in the presence of relatively large numbers of non-typical coliform organisms.

\section{CONCLUSIONS}

A simple procedure has been perfected to differentiate Irregular Type II and Irregular Type VI from Bact. coli Type I. A tube of brilliant green bile broth and a tube of peptone water are inoculated from a positive MacConkey broth tube. Both tubes are then incubated for $24 \mathrm{hr}$. in a specially controlled $44^{\circ}$ water-bath. At the end of this time the brilliant green bile broth tube is read for gas production and the peptone water tube is tested for indole. A positive result from each test indicates the presence of Bact. coli Type I. 
This modified version of the $44^{\circ}$ test for the rapid identification of Bact. coli Type I has several advantages over existing tests. It is, for all practical purpoşes, specific for Bact. coli Type I. It enables the water bacteriologist to give an accurate estimate of the Bact. coli content of water within 2 days of drawing a sample as against 5 days by the plating method. There is also a saving in media, apparatus and labour required for isolation and differential tests. The time saved makes it possible to examine more samples each day so that water supplies and treatment plants can be more closely supervised and the purity of the supply more efficiently controlled.

The application of the method, outlined above, to water samples in the Tropics would be worthy of trial in view of adverse reports on the $44^{\circ}$ fermentation test emanating from certain eastern countries.

\section{REFERENCES}

American Public Health Association (1936). Standard Methods for the Examination of Water and Sewage, 8th ed. New York: American Public Health Association.

Batty-Smith, C. G. (1942). The Eijkman Test. J. Hyg., Camb., 42, 55.

BoIzot, G. E. (1941). An examination of the modified Eijkman method applied to pure coliform cultures obtained from waters in Singapore. J. Hyg., Camb., 41, 566 .

MackenzIE, E. F. W. (1938). Thirty-third Annual Report of the Director of Water Examination, Metropolitan Water Board.

Mackenzie, E. F. W. \& Hilton-Sergeant, F. C. (1938). The coliform bacilli and water supplies. J. R. Army med. Cps, 70, 14, 73.

Raghavachari, T. N. S. \& IYer, P. V. S. (1939). The coli aerogenes index of pollution used in the bacteriological analysis of water. Indian J. med. Res. 26, 867.

REPORT (1939). The bacteriological examination of water supplies. Rep. publ. Hith med. Subj., Lond., no. 71.

Whiskin, L. C. \& TAYLOR, E. W. (1945). Chlorination of mains and the defects of yarn as a jointing material. Trans. Instn Wat. Engrs, Lond., 50, 219.

Wilson, G. S., Twigg, R. S., Wright, R. C., Hendry, C. B., Cowell, M. P. \& MaIer, I. (1935). The bacteriological grading of milk. Spec. Rep. Ser. med. Res. Coun., Lond., no. 206.

(Received 3 January 1948) 